\title{
コンクリートへの塩分浸透と塩害環境の評価 CHLORIDE PERMEATION INTO CONCRETE AND ESTIMATION OF SALINE ENVIRONMENT
}

\author{
川上英男*, 脇 敬一** \\ Hideo KAWAKAMI and Keiichi WAKI
}

\begin{abstract}
Mortar and concrete specimens were exposed at sea side areas in Hokuriku district, located in the central part of Japan, for 4 years. The specimens consisted of 4 kinds of water cement ratio and they were exposed at two kinds of conditions, roofed and un-roofed.

The larger was the water-cement ratio of the specimens, the larger value of the chloride content was resulted. And the larger values of the chloride content was found in the specimens of roofed exposure than that of un-roofed group of the specimens.

The facts proved that the permeated chloride was governed not only by the atmospheric salinity but also by the properties of the specimens and the exposure condition.
\end{abstract}

\section{Keywords: exposure, ssline environment, chloride content, permeation, diffusion, cement-water ratio}

暴露、塩分摆境、塩分含有量、浸透、拡散、セメント水比

\section{1. まえがき}

海岸付近の鉄筋コンクリートでは、外部より浸透蓄積 した塩分によって鉄筋の腐食が促進され、鉄筋コンクリ 一トの寿命を著しく短縮することがある。この種の塩害 を生ぜしるる危険性は大気中の塩分濃度に支配され、そ の原因のほとんどは海塩粒子の飛来にあるとされている。 ての大気中の塩分濃度の地域分布やそのコンクリート 中への浸透蓄積の実態についての資料は極めて乏しい。

末ず海塩粒子の発生や内陸部への飛来という現象につ いては気象条件、海象条件、海岸からの距離、地形等多 くの要因が総合して影響を及ほし (1) 更にそれらが季節 的にも变動するので、その実態は極めて多様で、且つ地 域性に富むことが想定される。したがって、それを風向、 風速など特定の影響要因別に系統的に把握することは極 めて困難である。

そてで提案されている指標の一つに海岸からの距離が ある。とれについてはISO ${ }^{(2)}$ 、日本道路協会 ${ }^{(3)}$. 樫野
(4)の提案があり、また建設省によるステンレス板によ る塩分捕集調查 ${ }^{(5)}$ や橋梁等実構造物の被害実態調查に 基づく塩害対策必要地域の設定が行われている。しかし ながら海岸からの距離とコンクリート中の塩分濃度（塩 害危険度）の関係にういては地域差が大きいとと ${ }^{(8,7)}$ を考えるとより適切な塩害対策にはきめ細かい，範囲の地 域設定が必要である。

さらに、塩害危険度の実態把握を困難にしている理由 の一つは、コンクリートに飛来付着した海盐粒子が降雨 雪によって洗い流され、大気中での捕捉塩分の年間の積 算值がそのまま鉄筋コンクリート各部の塩害危険度の大 小に対応しない可能性が考えられることである。とのて とは、海岸地域の建物の外頪に用いた亜鉛引き鉄板では、 雨がかりになっている下方部は健全であるのに、却って 雨の掛からない軒下部分が錆びているといった現象から も想定される。

そてで本研究では海塩環境に試験体を暴露し、コンク

\footnotetext{
* 福井大学工学部環境設計工学科 教授.工博 Prof., Dept. of Architecture and Civil Eng., Faculty of Eng., Fukui ** 福井大学工学部環境設計工学科 文部技官 Univ., Dr. Eng.

Technician, Dept. of Architecture and Civil Eng., Faculty of Eng., Fukui Univ.
} 


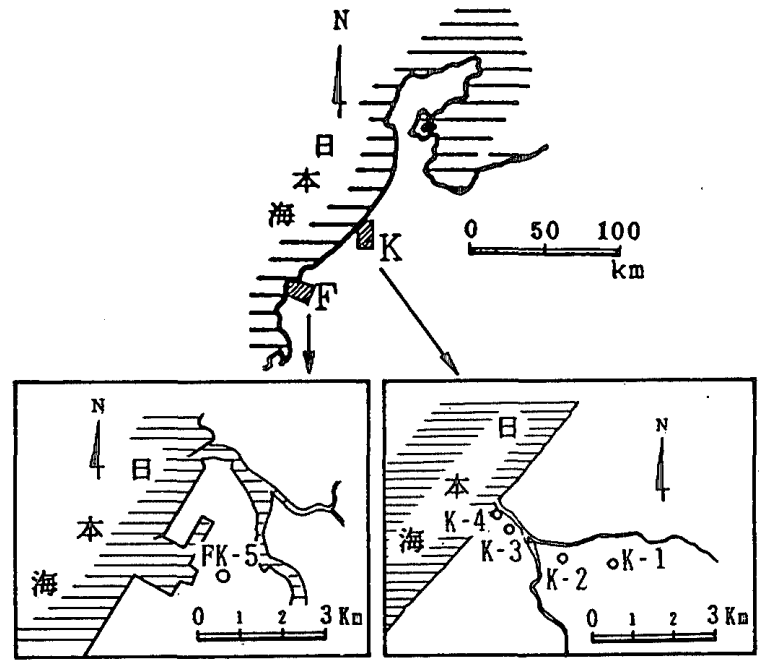

图 1 暴露地点

リート中への塩分の浸透蓄積の実態を明らかにするてと を試みた。すなわち、北陸地方の内、图 1 に示すF及び $\mathrm{K} の 2$ 地域にモルタル及びコンクリート試験体を 4 年間 暴露し、そこに浸透蓄積した塩分の分析結果から塩分の 浸透蓄積に及ぼす水セメント比、及び雨よけのフードの 有無によるコンクリートの乾湿条件の影響を検討した。 なお一旦コンクリートに浸透した塩分の一部はセメント と結合してフリーデ氏塩を形成し、鉄筋の腐食に関与 するのはその残りの溶解塩分とされているてとから、本 報告では溶解塭分を対象とした。また、拡散理論を適用 して耐久性上設定された許容塩分濃度に達する期間を試 算し、鉄筋コンクリートの塩害対策を必要とする範囲に つても考察した。な颃、本報告は既報の 1 年、 2 年 ${ }^{(8 .}$ ${ }^{\theta)}$ 及び 4 年間の暴露試験結果 ${ }^{(10)}$ をとりまとめたもので ある。

\section{2 試験体及び暴露条件}

暴露試験体用材料は表 1 亿示す通りである。

調合は表 2 に示すように 4 水準の水セメント比を対象 とした。モルタルはこれらの調合から粗骨材を除いたも

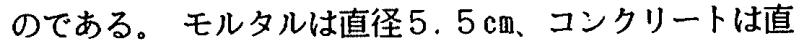
径 $10 \mathrm{~cm}$ の塩化ビニールパイプ（長さ $90 \mathrm{~cm}$ ）に詰 め16 日間密封養生後、長さ $15 \mathrm{~cm} に$ 切断、脱型した。乙 れらを室内において気乾状態とし、端面を残して遮塩性 塗料を塗布した。コンクリート試験体は表 2 の調合のう ち水セメント比 $45 \%$ と $65 \%$ の 2 種類を対象とした。砂利 自体は塭分の浸透にあまり関係しないと考えられること、 また、浸透塩分の分析においても、試料中の砂利の多少 が試料全体に対する塩分量の比率に影響し、分析値の信 頼性を低下させる恐れが大きいととを考えて、暴露試験 体はモルタルを主とした。な找、使用材料中には塩分は
表 1 使用材料

\begin{tabular}{|c|c|c|c|c|}
\hline & \multicolumn{4}{|c|}{ 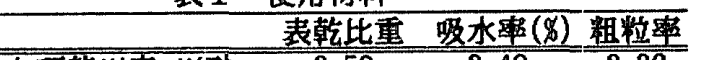 } \\
\hline 骨材 & 九豆 & $\begin{array}{l}2.59 \\
2.64 \\
\end{array}$ & $\begin{array}{l}2.49 \\
1.68 \\
\end{array}$ & $\begin{array}{l}2.36 \\
7.00 \\
\end{array}$ \\
\hline 対ト & $\begin{array}{l}\text { 竟通 } \\
\text { 压縮枵 }\end{array}$ & גント & 比重:3.15 & \\
\hline
\end{tabular}

\begin{tabular}{|c|c|c|c|c|}
\hline \multicolumn{5}{|c|}{ 表2 調合表 $\left(\mathrm{kg} / \mathrm{m}^{3}\right)$} \\
\hline$H / C(X)$ & 水 & ex*1 & 醒 & 础利 \\
\hline 45 & 168 & 372 & 655 & 1190 \\
\hline 55 & 166 & 302 & 717 & $(1190)$ \\
\hline 65 & 165 & 255 & 774 & 1175 \\
\hline 70 & 157 & 227 & 818 & $(1175)$ is \\
\hline
\end{tabular}

\begin{tabular}{|c|c|}
\hline & \\
\hline 梦令 & 售储作業及ひ盖生 \\
\hline （打設後） & 䔽ビパイプ内密封荃生 \\
\hline 16日 & 切断・脱型・室内保存 \\
\hline 60 日 & 玨料ユーテイング開始 \\
\hline 73日 & K-1 K-4䅗露開始 \\
\hline 83日 & FK- \\
\hline
\end{tabular}

殆ど含まれていないものと見なされる。てのととは後述 の分析結果に扣いて試験体内部の塩分浸透が及ばない部 分では塩分が検出されていないととにも現われている。 試験体の準備作業及び養生等を表 3 に示す。

暴露地点を図 1 亿示す。F地域 1 箇所 (海からの距離 $200 \mathrm{~m}$ ）、K地域 4 筒所（海加らの距離 $100 \mathrm{~m}-3 \mathrm{k} \mathrm{m}$ ）で、 試験体露出端面を海の方向に向けて水平に設置した。設 置場所は海風を遮るものの無い建物屋上またはン゙ンス とし、その高さは地上約 6-12 m（海面より約 $15 \mathrm{~m}$ -21 m) である。

暴露試験体 1 セットはモルタル 4 種各 3本、コンクリ 一ト 2 種各 1 本、計 14 本である。各暴露地点には雨よ けのフードを設けた 1セットとフード無し1セットを隣 接して設置した。暴露試験体各セットの状況を国 2 に、 暴露期間等の条件を表 4 亿示す。

\section{3 塩分分析}

回収したモルタル試験体は約 $1 \mathrm{~cm}$ 厚に輪切りにし、各 片を微粉砕して電気乾燥器 $\left(105^{\circ} \mathrm{C}\right)$ に入㧈、絶乾状態

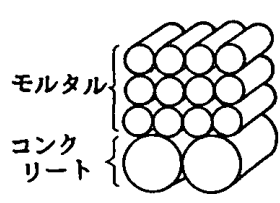

フード無し

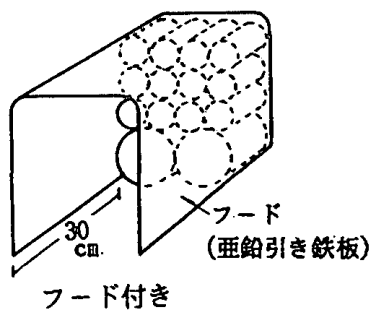

フード付き
图 2 試驗体暴露状识 
表4 暴露期間

\begin{tabular}{|c|c|c|}
\hline 暴贯地点 & 海加らの䤄䧸 & 暴露期間 \\
\hline $\begin{array}{l}\text { K 1 } \\
\text { K } 2 \\
\text { K } 3 \\
\text { K4 } \\
\end{array}$ & $\begin{array}{l}3.0 \mathrm{~km} \\
2.1 \mathrm{~km} \\
500 \mathrm{~m} \\
100 \mathrm{~m} \\
\end{array}$ & $\begin{array}{l}\int_{1991.6 .11}^{1987.7 .14} \\
(1428 \text { 日) }\end{array}$ \\
\hline F K 5 & $200 \mathrm{~m}$ & $\begin{array}{l}1987.7 .24 \\
1991 \text {.6.8 } \\
(1415 \text { 日) } \\
\end{array}$ \\
\hline
\end{tabular}

とした後、質量を測定する。これを $50{ }^{\circ} \mathrm{C}$ 精製水に浸潰、 瀶汼、2 4 時間以上経過後の上澄水を濾過し、これに対 して電量滴定法による塩分濃度計を用いて塩素イオン量 を測定した。コンクリート試験体は約 $1 \mathrm{~cm}$ 㴟に輪切りの 後、丁寧にハンマーで粗砕、丹念に砂利を取り除き、残 りのモルタル部について上記モルタルと同様の分析を行 った。塩素イオン量はいずれもモルタル絶乾質量に対す る百分率で表した。

\section{4. 塩分分析結果}

暴露地点 5 籄所の各モルタル試験体内部の塩分量を表 面からの深さとの関係で示したのか図3である。

各困にプロットした各データは輪切りにした試験体部
分の平均值を表すものである。海岸に最も近いK 4 地点 では塩分量が大きいので縦軸の目盛は他の場合の $1 / 2$ に 縮めてある。

コンクリート試験体の分析結果を同様に困 4 に示す。

\section{5 考察}

\section{1 試験体内の塩分分布}

どの暴露地点においても、試験体表面より内部への距 離（深さ）が大きくなるほど塩分量は少なくなっている のが一般的傾向である。中には表層部の塩分量が 2 層目 の塩分量より小さい場合も認められる。ての現象は水セ メント比の大きい試験体において顕著である。

JASS 5 の許容塩分量 $0.3 \mathrm{~kg} / \mathrm{m}^{3}$ (対コンクリート) は、 コンクリート中のモルタルとして $1100 \mathrm{~kg} / \mathrm{m}^{3}$ を見込むと きは対モルタル塩分量は $0.027 \%$ となる。它の值はコン クリート製造時の全塩分であるが、まえがきに述てたよ うに、ある経過年数以後の塩害は溶解塩分に起因すると ころから、これら両者を対比するてととした。

海岸から 500m以内では、この值を超える部分が多く 見受けられる。また通常の鉄筋位置として想定される深 さを表面から $3 \mathrm{~cm}$ とすると、これらの図に示すように、
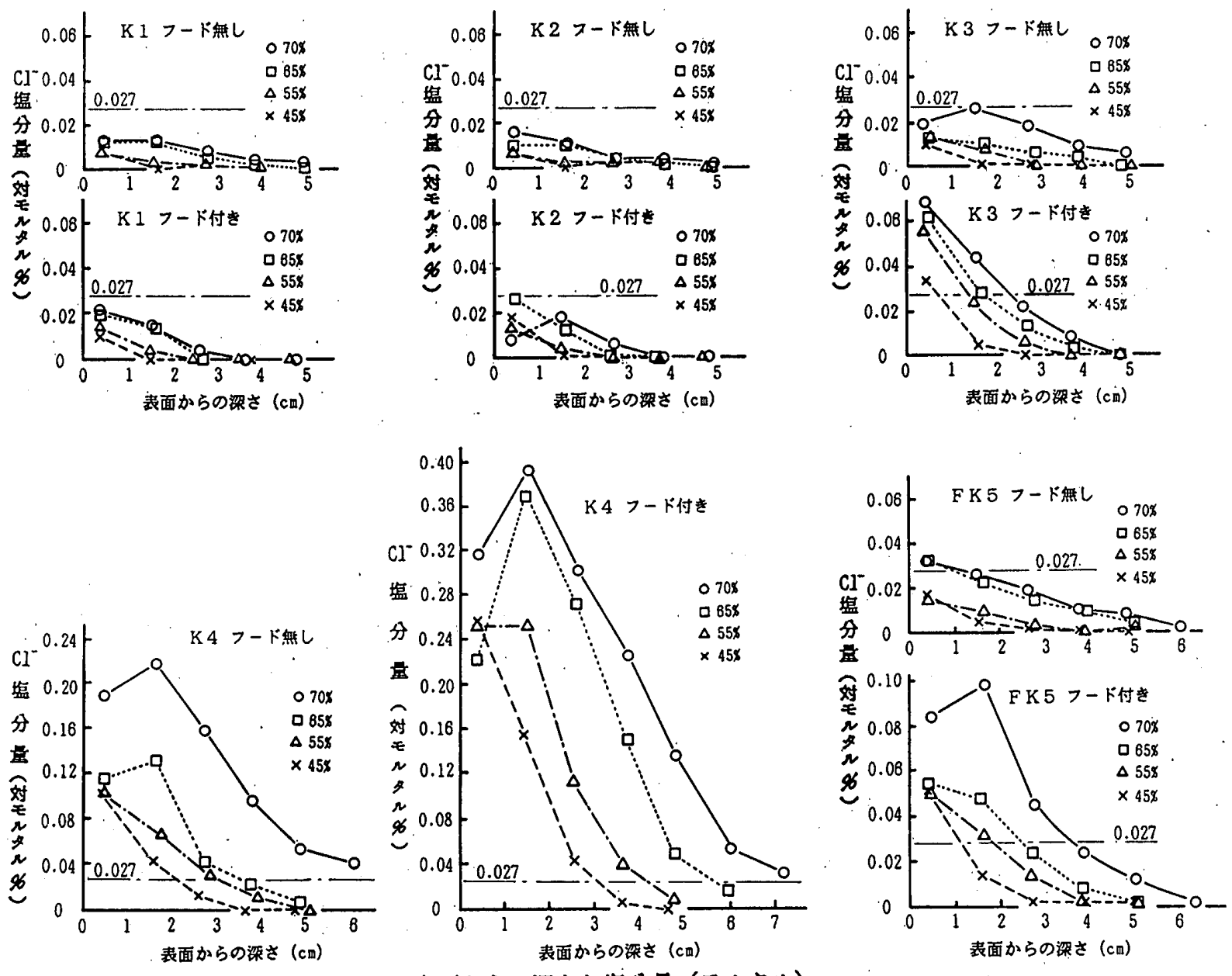

図3 表面からの深さと塩分量（モルタル） 

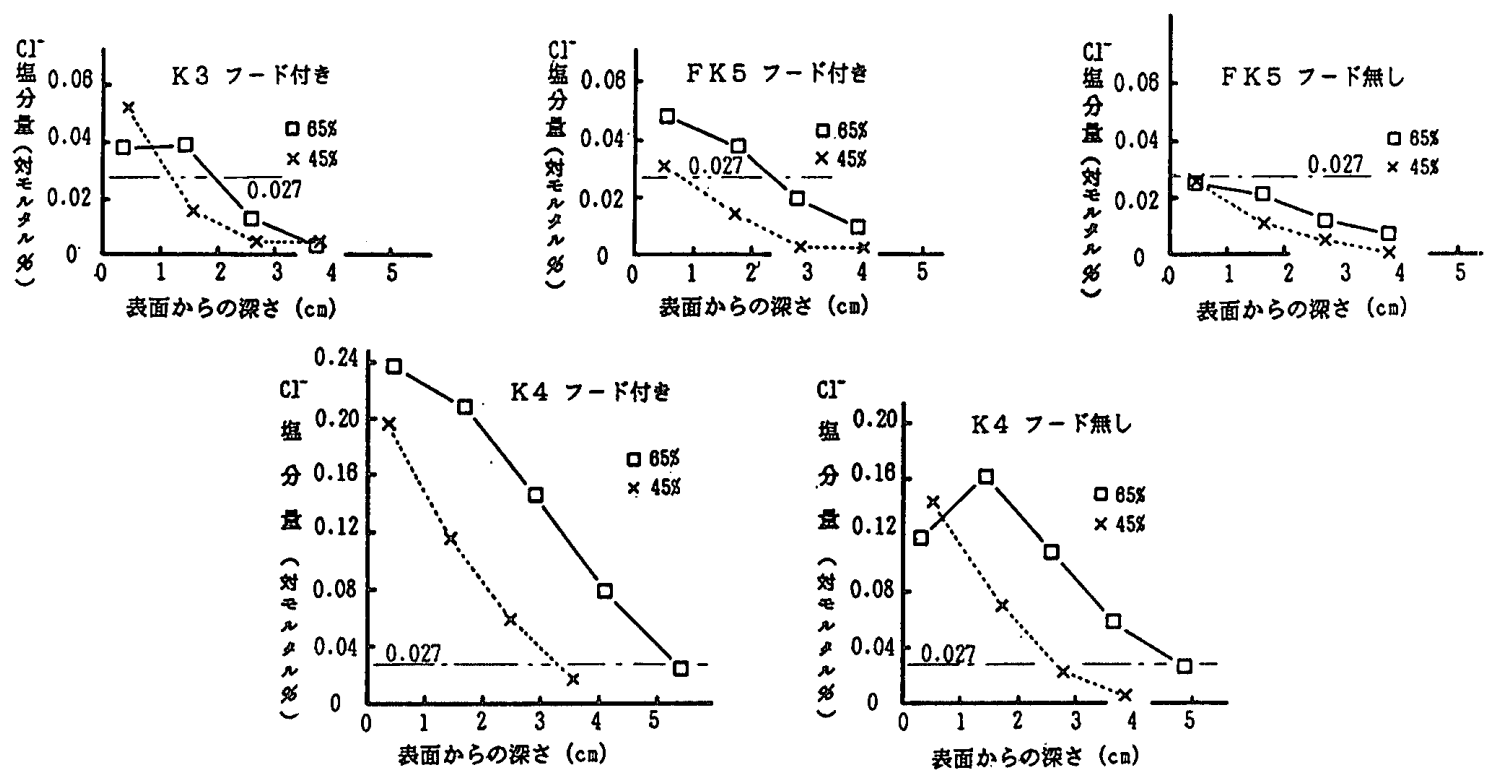

图4 表面からの潹さと塩分量（コンクリート）

すでにその值に達したり、または それを超えるものは、 海岸からの距離 $200 \mathrm{~m}$ （FK-5）のフード付き試験体では、 $\mathrm{w} / \mathrm{c}=70 \% 、 65 \%$ の場合であり、距離 $100 \mathrm{~m}(\mathrm{~F}-4)$ では フード無しの $\mathrm{w} / \mathrm{c}=45 \%$ の試験体を除いてすべての試験 体に及んでいる。

同一暴露地点、同一水セメント比の試験体ではフード 付き試験体表層部の塩分量はフード無しの場合に比へて、 塩分量は大きく、おおよそ2倍に達している。降雨雪に よって一旦飛来付着した塩分が流されるととが少ないた めと考えられる。試験体内部の塩分量も同一染さを比較 するとフード付きの方がフード無しの場合より大きい值 を示している。

同一地点内の試験体では 水セメント比 $(\mathrm{w} / \mathrm{c})$ が大 きい程、試験体内各部の塩分量は大きい值となっている。

\section{2 海岸加の距離と試験体表層部の塩分量}

一般的に海岸からの距離が大きくなるほど、各水セメ ント比の試験体内の各梁さにおける塩分量は減少してい る。試験体表層部の塩分量を海岸から暴露地点までの距 離に対応して示したのが図5である。
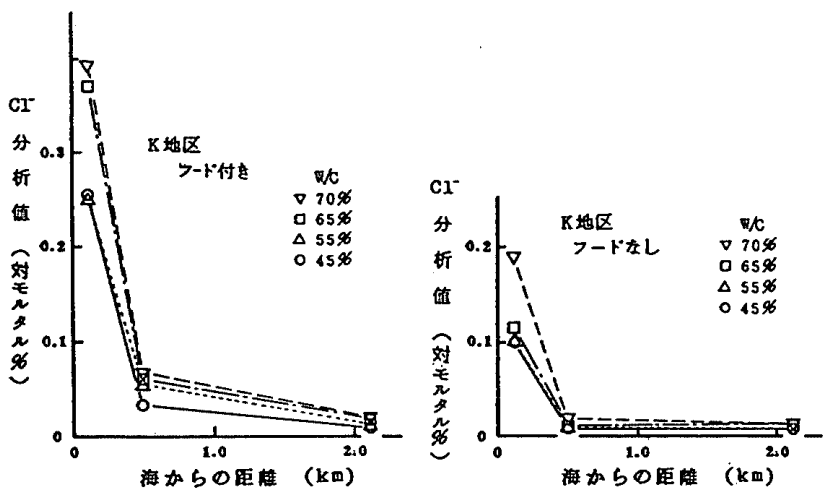

图5 海からの距嚾と表層部塩分量
フード付きの場合、表層部塩分量は，海岸からの距離 $100 \mathrm{~m}$ （k4地点）の場合に比べて $500 \mathrm{~m}$ （k3地点）では 約 1/6に減少し、2.1 k m地点 $(\mathrm{k}-2)$ では極好て小さ い值となっている。

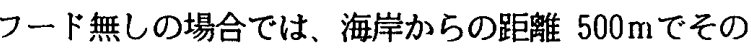
表層部塩分量は極めて小さくなり、 $2.1 \mathrm{k} \mathrm{m}$ 地点の場合 と殆ど同程度となっている。

てれらの結果は、この地域では海岸より $100 \mathrm{~m}$ の地点 に比べ $500 \mathrm{~m}$ 以遠の地点では塩分のコンクリート中への 蓄積が大幅に減少することを示している。

\section{3 コンクリートとモルタルの比較}

図3及び図4によるとコンクリートとモルタルでは試 験体の表面から内部に向からほど塩分量が減少する傾向 はほほ同様である。叉塩分量そのものは各暴露地点毎に 両者の間にやや差が見られるが、どちらが大きいと言っ た一定の傾向は見られない。すなわち塩分浸透慜積状況 はほほ同様と見做しろる。この点については次節でも述 べる。

\section{4 塩分浸透特性}

上記の結果にもとずき、各試験体内部の塩分分布に対 してFickの拡散方程式の解（式（1））を適用し、最小 自乗法を用いて見かけの表面塩分量（Co）之兒かけの 拡散係数 (D c ) を算定した。

$$
\begin{aligned}
& C=c_{0}\left[1-\operatorname{erf}\left(\frac{x}{2 \sqrt{D_{C} \cdot t}}\right)\right] \\
& \mathrm{C}: \mathrm{x} \text { に扔ける塩分量 erf : 誤差関数 } \\
& \mathrm{C} 0_{0} \text { : 見かけの表面塩分量 } \mathrm{x} \text { : 表面からの距離 }(\mathrm{cm}) \\
& \mathrm{Dc} \text { : 見かけの拡散係数 } \mathrm{t} \text { : 暴露期間 }(\mathrm{sec})
\end{aligned}
$$

試験体の表面から第一層目の塩分量が第 2 層目の値よ り少なく、叉2 層目以降の塩分量の分布傾向より大きく 


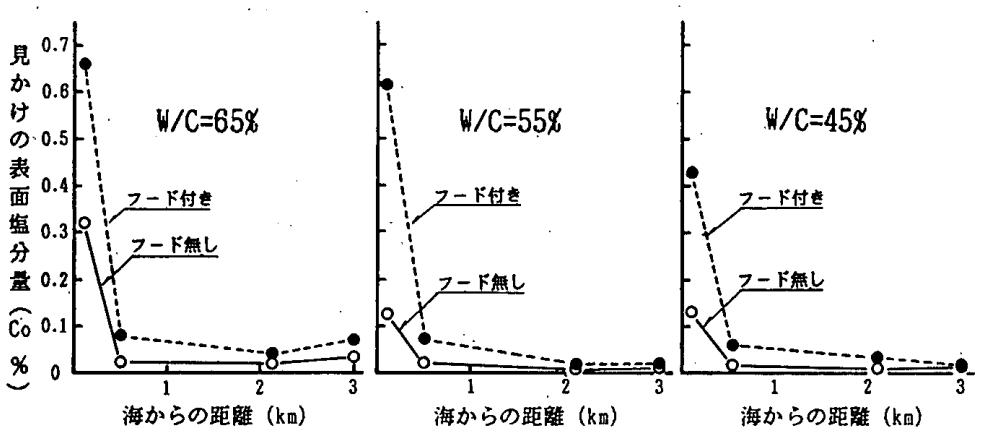

図6 海からの距踓と見かけの表面塩分量

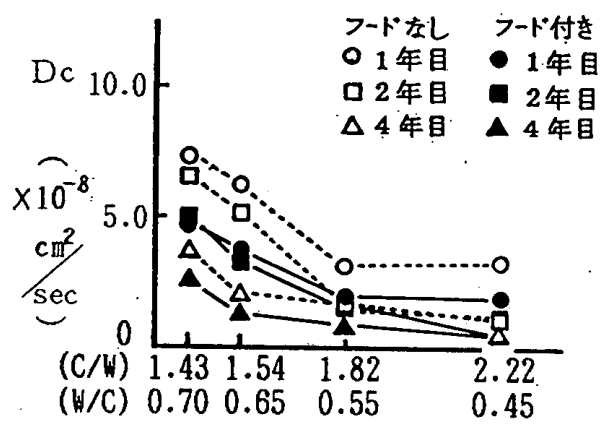

因 7 セメント水比・水セメント比と拡散保数
外れている場合は、第2 層目以降の塩分量のデータを解 析の対象とした。とのような場合はC。の算定值は表層 の塩分分析值よりかなり大きい值となるが、試験体内部 の塩分分布をより忠実に反映するものと見做される。

a ) 見かけの表面塩分量 $(\mathrm{C} 0)$.

$\mathrm{Co \sigma}$ 值を水セメント比 (w/c) 別に、海岸からの距 離に対してプロットしたのが困6である。

海岸より $100 \mathrm{~m}$ 地点（K 4 ）ではフードの有無に拘 わらず、Coは水セメント比が大きいほど、大きい值を 示している。すなわち同じ海塩環境下にあっても、内部 への塩分浸透を特幑づける指標としてのC oは 同一值を 示さず、モルタルの水セメント比に依存することを示し ている。海岸よりの距離が大きい場合は塩分量の絶対值 が小さいので、その差も小さく、上記の傾向を見分けら れるほどには至らない。

b ) 見かけの拡散係数 (D c )

見かけの拡散係数 D c は試験体の水セメント比が同一 であっても暴露地点によってバラツキがあるので、それ らの值の水セメント比及びセメント水比ごとの平均値を 困7に示す。

D c の平均值は水セメント比が小さいほど、小さくな っており、同一表面塩分量に対しては内部への浸透塩分 量を低く押さえられるととを示している。

一方、どの水セメント比の場合においても D c はフー ド付きの場合の方がフード無しの場合に比べて小さい值 となっている。とのととは同じ水セメント比のモルタル やコンクリートでもその環境条件（フードの有無による 乾湿度の差など）によって拡散係数が異なることを示し ている。

\begin{tabular}{|c|c|c|c|c|}
\hline 表 5 & \multicolumn{4}{|c|}{$\begin{array}{l}\text { 表面から } 3 \mathrm{~cm} \text { 位置でCI }{ }^{-} \text {が } \\
0.3 \mathrm{~kg} / \mathrm{m}^{3} \text { に迲する暴露期間 (年) }\end{array}$} \\
\hline W/C & & 海から & 距㺟 & \\
\hline$(8)$ & $100 \mathrm{~m}$ & $500 \mathrm{~m}$ & $2.1 \mathrm{~km}$ & $3.0 \mathrm{~km}$ \\
\hline 45 & 3.9 & 106.5 & 2064.4 & - \\
\hline 55 & 2.8 & 19.8 & - & - \\
\hline 65 & 1.2 & 11.2 & 106.1 & 154.2 \\
\hline 70 & 0.7 & 6.3 & 38.8 & 46.9 \\
\hline
\end{tabular}

また同困は暴露期間が長期になるほど D c の值は小さ くなることを示している。これには試験体の材令が進ん で材質が緻密化したてとも関与しているものと考えられ る。

c）塩分蓄積の推定

(1)式によれば CoとD c が与えられると、ある期間

( $\mathrm{t}$ ）における表面からの距離 $(\mathrm{x})$ に対応する塩分量

（C）が求められる。今仮に暴露期間 4 年のC o と D c を用いて、表面からの染さ $3 \mathrm{~cm}$ (通常の鉄筋コンクリ 一トに扣ける鉄筋の位置を想定）に招ける塩分量が 0.3 $\mathrm{kg} / \mathrm{m}^{3}$ (JASS 5，鉄筋の腐食を防止する観点から定めた コンクリート中の $\mathrm{Cl}^{-}$イオンの上限值）に達する期間 ( $\mathrm{t}$ 年) を算定した。その結果を表 5 に示す。

同表中の空橍は暴露期間 4 年のC 0 の值が $0.3 \mathrm{~kg} / \mathrm{m}^{3}$ （対モルタル 0.027\%）に達していないので（1）式を 適用するに至らなかったものである。

それらの $\mathrm{t}$ の算定值を海岸から暴露地点までの距離と の関係で示したのが図8である。座標軸は両対数目盛と してある。海岸からの距離 $500 \mathrm{~m}$ 地点でもw/c が $55 \%$ より大きいときは 通常のRC建物の耐用年数 65年に至 らない内に $0.3 \mathrm{~kg} / \mathrm{m}^{3}$ に達する。このように同困は海

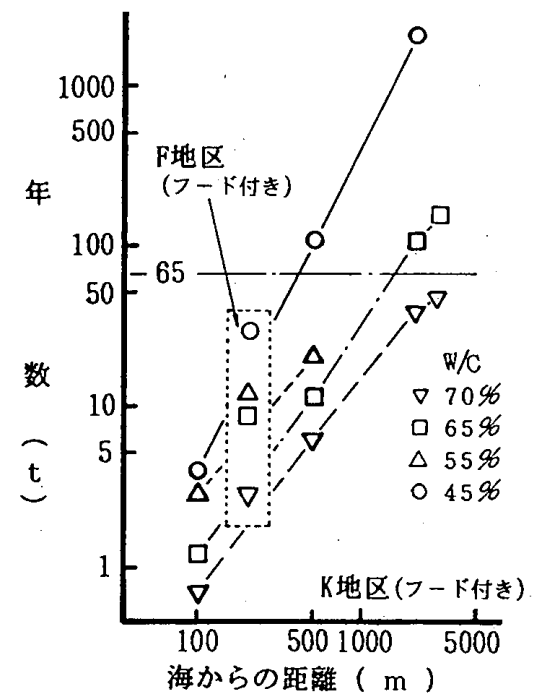

図 8 海加らの距略と塩分限度到達年数 
岸からの距離と $\mathrm{t}$ との関係を与えるものとなる。ただし、 てれらの関係は暴露時までの試験体の養生条件によって も異なると考えられるので、上記の数值は一心の参考值 である。しかし、この手法は多年に及ふ塩分の蓄積を推 定する可能性を示すものと考えられる。

また、F地区 海岸加ら $200 \mathrm{~m}$ 地点の算定值を図 8 亿破 線で囲んで示す。これらの值は、K地区の同列地点の年 数より大きく、塩害危険度は $\mathrm{K}$ 地区より小さいととを意 味する。な括 图8に扔いて海岸からの距離と $\mathrm{t}$ はほほ 直線的関係となっているが、その普遍性については、塩 分環境の地域依存性とあわせて検証する必要がある。

こてではC o. D c の值は暴落 4 年の場合を採用してい る。今後材質は安定していると見做されるので D c の值 はそれほど変化するとは考えにくいが、C o の值は、そ の経年変化を図 9 に示すように、一部例外はあるが年々 増加している。また、参考までに図 3 の塩分量分布から 浸透塩分の総量（塩分分布困の面積）と暴露期間との関 係を図 10 亿示す。

これらの浸透塩分増加の傾向考えると、暴露期間 4 年 のデータに基づいて算定した上記のそれぞれの值は、よ り長年月の予測に対してはいずれもさらに大きい塩分量 となる可能性があるととを示している。

\section{6 むすひ}

北陸地方の海岸地域に 4 年間屋外暴露したモルタル及 びコンクリート中の可溶性塩分分析及びその考察から、 塩分の浸透蓄積について、海岸からの距離を始め、水セ メント比やフードの有無など材質や暴露条件ことに、そ の実態を明らかにし、この手法が塩害対策地域区分の設 定に有力な手段となり得るととを示した。叉、塩分の浸 透現象について明らかになった事項を要約すると次の通 りである。

1) 試験体各部の浸透塩分量は同地点、同水セメント

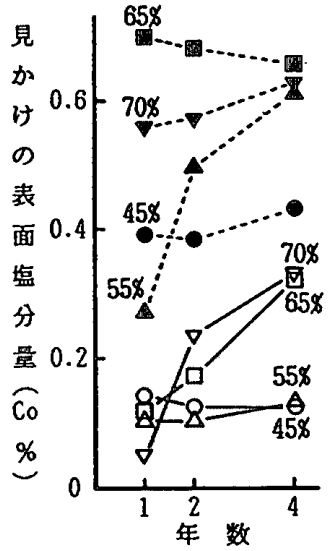

図9 暴露期間と見かけの 表面塩分量

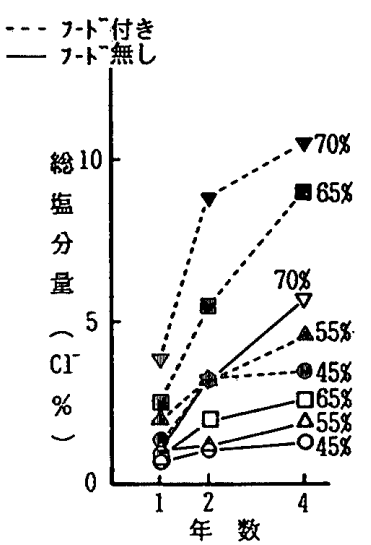

図10 暴露期間と溶解監分総量
比の場合、フード付きの方がフード無しの場合に比べて 大きく、約 2 倍の塩分量を示した。叉同地点、同暴露条 件のもとでは水セメント比の大きい場合ほど試験体各部 の塩分量は大きい值を示した。すなわちコンクリートや モルタルに浸透蓄積する塩分は必ずしも大気中の塩分濃 度だけで一義的に決まるものでなく、コンクリート、モ ルタルの材質条件や、雨がかりの有無などの環境条件が 関与することが示された。

2) 拡散理論解を用いて塩分浸透量を推定する場合の 根拠となる見かけの表面塩分量についても同様に水セメ ント比、フードの有無によって異なった值となり、同一 地点に対して一定の值を想定できないてとが明らかとな った。叉この值は暴露期間とともに大きくなるととも示 された。

コンクリートやモルタルへの塩分の蓄積状況に扔いて は地域差が顕著である。それらに対応する塩害対策の地 域区分は小範囲が望ましく、できれば本報告の手法によ って多数の試験体を一斉に各地に暴露するのが望ましい が、そのような資料が整わないうちは、塩害を受けるこ とのないように充分な対策を講ずる配慮が必要である。

\section{謝辞}

本研究の塩分分析扣よび理論的解析には福井大学学生、 南弘子、平井美穂、川上英昭の諸君の協力を得て。こて に記して謝意を表します。

参考文献

1）たとえは，堀田健治：砂浜海岸における海塩粒子の発生 に関する研究、日本建築学会構造系論文集、第444号, pp. 145-152, 1993.2

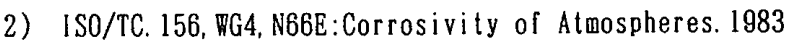

3）日本道路協会 : 道路橋の塩害対策指針（案）同解説、 1984.2

4）樫野紀元：RC造建築物における塩害地域区分の設定に つての一考察、日本建築学会関東支部研究報告集，1983

5）建設省：コンクリートの耐久性向上技術の開発報告書 (第一編)（第二編），建設省総合技術開発プロジェクト， 1988. 11

6）川上英男：北陸地方の環境塩害危険度分布について，第 8 回コンクリート工学年次講演会論文集, pp. 81-84, 1986

7）川上英男: 北陸地方の塩分環境: 日本建築学会大会学術講 演梗概集A, pp. 265-266. 1987. 10

8）川上英男 : 塩害環境とモルタル中の塩分蓄䅡、日本建筑学 会大会学術講演梗概集 A, pp. 631-632, 1989.10

9）川上英男 : 塩害環境とモルタルへの塩分蓄積、日本建築学 会大会学術講演梗概集 A, pp. 131-132, 1990. 10

10）川上英男 : 塩害環境とモルタルへの塩分蓄積（影露期間 4 年の場合), 日本建築学会大会学術講演梗概集: A,$p p$. 1065-1066, 1992.8

(1993 年 4 .月 8 日原稿受理, 1993 年 8 月 16 日採朋決定) 